\section{Absence of anti- trifluoroacetate antibody after halothane anaesthesia in patients exhibiting no or mild liver damage}

Yoshiro Sakaguchi MD, ${ }^{*}$ Shoichi Inaba DM Sc MD, $\dagger$ Kazuo Irita DM Sc MD, ${ }^{*}$ Hironori Sakai DM Sc MD $\ddagger$ Hajime Nawata DM Sc MD, $\$$ Shosuke Takahashi DM Sc MD*
It has been shown that the circulating antibodies, which bind to rat hepatic microsomal proteins obtained afier in vivo exposure to halothane, are detectable by immunoblotting in patients with "halothane hepatitis (HH)," and that rabbit immunized anti-sera against trifluoroacetylated rabbit serum albumin (TFA-RSA) recognizes rat microsomal distorted polypeptides in almost the same way as do sera from patients with $\mathrm{HH}$. In this paper, we report first the development of a novel method of synthesizing TFA-RSA using p-nitrophenyl TFA, and second the results of tests for circulating anti-TFA antibodies in the serum of 86 patients who had received halothane anaesthesia and developed no (67 patients) or mild (19 patients, the maximum activity of serum alanine aminotransaminase 519 $\left.I U \cdot L^{-1}\right)$ liver damage. Serum was selected from stored sera of post-transfusion patients. The new method of synthesizing TFA-RSA was convenient and was able to be done at neutral pH. Rabbit sera obtained after immunization with the newly synthesized TFA-RSA recognized the same polypeptides (109 $k D a, 92 k D a, 80 k D a, 76 k D a, 64 k D a$ and $59 k D a)$ as the established anti-sera against TFA-RSA, and these reactions were inhibited in the presence of TFA-lysine. Cinculating antibodies

\section{Key words}

ANAESTHETICS, VOLATILE: halothane;

LIVER: hepatitis, toxicity.

From the Department of Anesthesiology and Critical Care Medicine,* Blood Transfusion Service, ${ }^{\dagger}$ and the Third Department of Internal Medicine, $\ddagger$ Faculty of Medicine, Kyushu University, Fukuoka 812, Japan.

Address correspondence to: Dr. Yoshiro Sakaguchi, Department of Anesthesiology and Critical Care Medicine, Faculty of Medicine, Kyushu University, 3-1-1Maidashi, Higashi-ku, Fukuoka 812, Japan.

Accepted for publication 29th January, 1994. were not detected in our patients who had developed no or mild liver damage. The present finding supports the hypothesis that the appearance of circulating antibodies against microsomal distorted proteins are specific to patients with $H H$. Furthermore, we have shown here that the halothane-induced mild increase in ALT activity is not associated with the appearance of those circulating antibodies, supporting the pathophysiological difference between $\mathrm{HH}$ and halothane-induced mild hepatic damage.

On a montré que les anticorps circulants qui se lient au protéines microsomiques hépatiques du rat après une exposition in vivo à l'halothane peuvent être détectés par immunotransfert chez les patients atteints d' hépatite à l'halothane (HH) ». On a montré aussi que les anti-sérums de lapins immunisés contre l'albumine sérique trifluoroacétylée (TFA-RSA) reconnaissaient les polypeptides microsomaux déformés de rat de façon presque identique au serums de patients atteints d'HH. Dans cet article, nous rapportons d'abord le développement d'une nouvelle technique de synthèse de TFA-RSA à partir du p-nitrophényl TFA, et deuxièmement le résultat d'épreuves de détection des anticorps anti-TFA dans le sérum de 86 patients qui ont été anesthésiés à l'halothane et n'ont pas présenté (67 patients) ou ont présenté une lésion hépatique légère (19 patients dont l'activité de l'analine aminotransaminase n'a pas dépassé 519 $\left.U I \cdot L^{-1}\right)$. Le sérum a été choisi parmi des sérums stockés après transfusions. La nouvelle méthode de synthèse de la TFA-RSA est pratique et réalisable avec un $\mathrm{pH}$ neutre. Les sérum de lapins obtenus après immunisation avec la nouvelle TFA-RSA de synthèse ont reconnu les mêmes polypeptides (109 kDa, 92 $k D a, 80 k D a, 76 k D a, 64 k D a$ et $59 k D a)$ que les anti-sérum TFA-RSA éprouvés, et ces réactions ont été inhibées en présence de TFA-lysine. Les anticorps circulants n'ont pas été décelés chez nos patients sans atteinte ou avec légère atteinte hépatique. Ces données supporte l'hypothèse selon laquelle l'apparition d'anticorps circulants contre les protéines microsomi- 
ques déformées sont spécifiques aux patients atteints de $\mathrm{HH}$. Nous avons montré de plus, que la légère augmentation de l'acitivité de l'ALT n'est pas associée avec l'apparition de ces anticorps circulants, ce qui supporte la différence physiopathologique entre l'HH et la lésion hépatique légère induite par l'halothane.

The introduction of enflurane, isoflurane and sevoflurane has led to the decreased use of halothane for anaesthesia, in part because anaesthetists fear the threat of fatal hepatic necrosis which has been reported to occur after halothane anaesthesia. This severe hepatic failure is so-called "halothane hepatitis $(\mathrm{HH})$ ". ${ }^{1}$ Furthermore, halothane has been known to induce mild liver damage other than $\mathrm{HH}$. We previously reported that halothane increased serum alanine aminotransferase (ALT) activity to more than 70 $\mathrm{IU} \cdot \mathrm{L}^{-1}$ in $24 \%$ (226 of 928 ) of anaesthetized patients without blood transfusion, none of whom developed HH. ${ }^{2}$ Halogenated inhalation anaesthetics have been shown to be metabolized by the microsomal mixed function oxidase system, ${ }^{3}$ and the incidence of severe hepatic dysfunction seems to be lower as the rate of biotransformation decreases. The mechanisms causing the development of $\mathrm{HH}$ have not been clarified, but there seem to be two possibilities. ${ }^{1,4-7}$ First, halothane may undergo reductive metabolism under hypoxic conditions, and the resultant metabolites (halogen radicals) are toxic to the liver. Second, trifluoroacetate (TFA), a product of oxidative biotransformation ${ }^{8,9}$ covalently binds to the lysine residues of proteins, and the resultant distorted proteins act as antigens to immune responses.

Recently, Kenna et al. revealed the appearance of circulating antibodies in sera from patients with $\mathrm{HH}$ : those antibodies bind to rat hepatic microsomal proteins obtained after in vivo exposure to halothane. ${ }^{10}$ The observed antigen-antibody reactions were completely blocked in the presence of TFA-lysine, indicating that these sera recognized the TFA-lysine complex of polypeptides in the liver microsomes. Because these circulating antibodies were not identified in sera taken from patients who had received halothane anaesthesia but did not develop $\mathrm{HH}$ (control patients), they concluded that these antibodies are specific to patients with HH. However, the total number of control patients negative by enzyme-linked immunosorbent assay (ELISA) reported in the literature is only $27,{ }^{11-13}$ which is too small a sample for meaningful comparison with the incidence of $\mathrm{HH}, 7$ of 250,000 anaesthetized patients. ${ }^{14}$

Kenna and coworkers have also shown that the rabbit anti-sera, which are elicited against trifluoroacetylated rabbit serum albumin (TFA-RSA), recognize the rat microsomal polypeptides in almost the same way as do

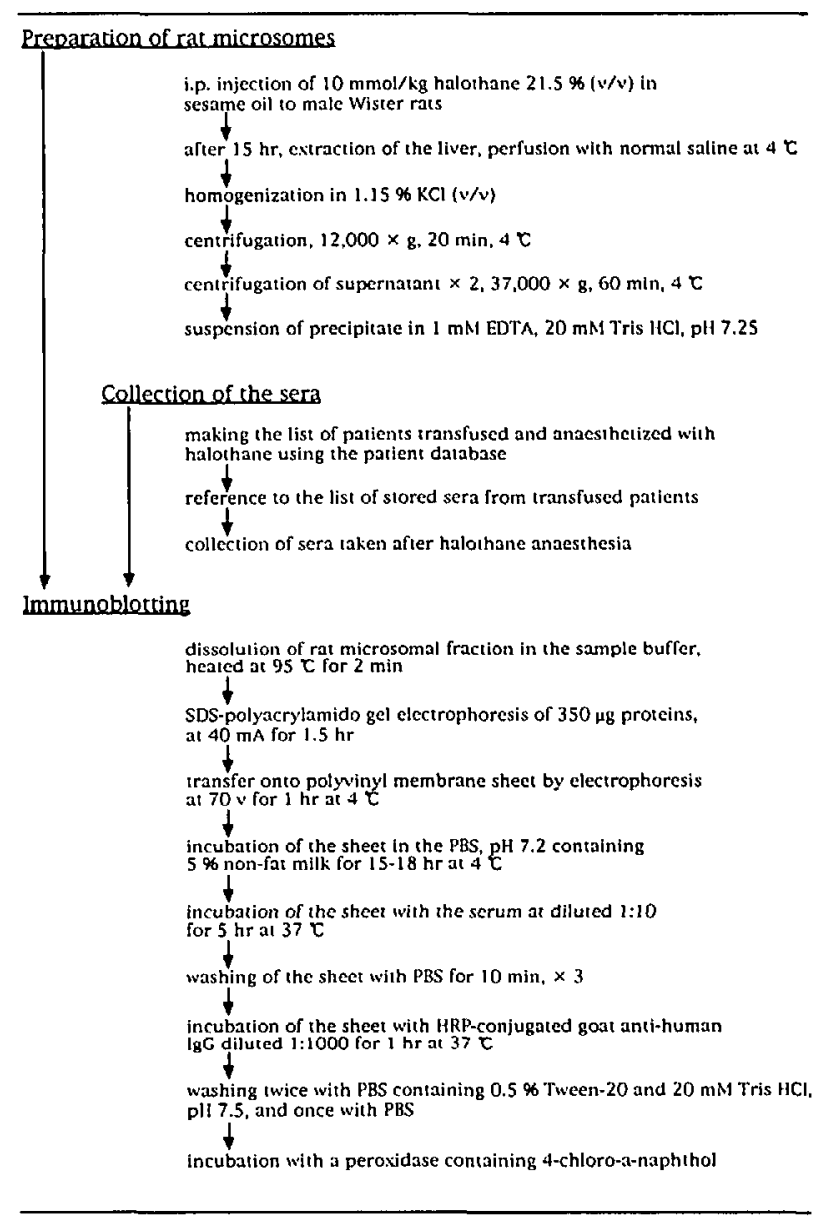

FIGURE I Flow diagram of the procedure.

sera from patients with $\mathrm{HH} .{ }^{10}$ Since $S$-ethylthioltrifluoroacetate, which they used to synthesize TFA-RSA is not commercially available, we established an assay for the detection of anti-TFA antibody in patients anaesthetized with halothane.

Because halothane has not been used since 1989 at the Kyushu University Hospital, where we anaesthetize 5,000 patients per year, a prospective study of sera after halothane anaesthesia was not possible. Fortunately, about 20,000 sera stored in our blood bank for a survey of post-transfusion hepatitis were available, among which were the sera of 86 patients who had developed no or mild liver damage, none of whom had developed $\mathrm{HH}$ after having been anaesthetized with halothane. In this paper, a new method of synthesizing TFA-RSA using p-nitrophenyl TFA is described, and the detection of circulating antibodies in 86 sera is studied.

Methods

Our experimental procedure has been performed as shown in Figure 1. 


\section{Chemicals}

Electrophoresis chemicals, molecular weight markers, polyvinyl membrane sheets, and 4-chloro-1-naphthol were obtained from Bio-Rad Laboratories (Richmond, CA). Halothane and sesame oil were from Hoechst Japan Co. (Tokyo, Japan) and Nacalai Tesque Inc. (Kyoto, Japan), respectively. Rabbit serum albumin, N-e-trifluoroacetylL-lysine (TFA-lysine) and trifluoroacetate anhydride were from Sigma Chemical Co. (St. Louis, MO). P-nitrophenyl TFA was from Aldrich Chemical Co. (Milwaukee, WI). Horseradish peroxidase-conjugated goat anti-human IgG and goat anti-rabbit IgG were from Organ Teknica (Cappel; West Chester, PA). 1-ethyl-3-(3-dimethylaminopropyl) carbodiumide hydrochloride was from Wako Pure Chemical Industries (Osaka, Japan). Complete Freund's adjuvant was from Difco Laboratories (Detroit, MI).

\section{Patients'sera}

Using the patient database in our integrated hospital information system, a list of patients who had been transfused and anaesthetized with halothane was made along with information about the dates of anaesthesia. About 20,000 sera from transfused patients have been stored and registered in our blood bank with consecutive numbers identifiable as to the patient for a survey of posttransfusion hepatitis. From the stored sera we succeeded in collecting the sera, taken after halothane anaesthesia, of all 86 patients who met our criteria and which sera was of sufficient volume for analysis ( 39 male and 47 female; mean age $26.1 \pm 26.7 \mathrm{yr}$, range 0 to 77 ). The intervals between the halothane anaesthesia and the drawing of the sera averaged 151 days (range 14-1170); 2-4 weeks in 15 patients, 5-8 weeks in 39 patients, 9-12 weeks in nine patients, 13-16 weeks in two patients, 17-20 weeks in two patients and more than 20 weeks in 19 patients. Serum ALT activity increased to over 70 $\mathrm{IU} \cdot \mathrm{L}^{-1}$ (normal range 5-33 IU $\cdot \mathrm{L}^{-1}$ ) in 19 patients. The maximum ALT activity observed was $519 \mathrm{IU} \cdot \mathrm{L}^{-1}$.

\section{Preparation of liver microsomes from halothane- administered rats}

Institutional approval for the study was obtained from the Animal Care and Use Committee of Faculty of Medicine, Kyushu University. Halothane, which was dissolved in sesame oil at a concentration of $21.5 \%(\mathrm{v} / \mathrm{v})$, was administered intraperitoneally to three male Wistar rats weighing about $150 \mathrm{~g}$ at a dose of $10 \mathrm{mmol} \cdot \mathrm{kg}^{-1}$. Control rats were not exposed to halothane. Rats were anaesthetized with diethyl ether and liver samples were taken $15 \mathrm{hr}$ after the halothane injection.

Microsomal fraction was prepared as reported. ${ }^{15}$ The liver samples were perfused immediately with normal saline solution at $4^{\circ} \mathrm{C}$, and then homogenized by the Potter-
Elvehjem homogenizer (three strokes) in $1.15 \% \mathrm{KCl}(\mathrm{v} /$ v), followed by a centrifugation at $12,000 \times \mathrm{g}$ for 20 min at $4^{\circ} \mathrm{C}$. The supernatant was centrifuged at 37,000 $\times \mathrm{g}$ for $60 \mathrm{~min}$ at $4^{\circ} \mathrm{C}$. The resultant precipitate was suspended in $1.15 \% \mathrm{KCl}$ and was centrifuged again at $37,000 \times \mathrm{g}$ for $60 \mathrm{~min}$ at $4^{\circ} \mathrm{C}$. The final precipitate was suspended in $1 \mathrm{mM}$ EDTA and $20 \mathrm{mM}$ Tris $\mathrm{HCl}, \mathrm{pH}$ 7.25 , and stored at $-80^{\circ} \mathrm{C}$. The protein concentration of the obtained liver microsomal fraction was 34.7 $\mathrm{mg} \cdot \mathrm{ml}^{-1}$.

\section{Immunoblotting}

The rat liver microsomal fraction was dissolved in the sample buffer: the final concentration of the sample buffer was $2 \%$ (w/v) SDS, $0.71 \mathrm{M} \beta$-mercaptoethanol, $1.36 \mathrm{M}$ glycerol, $1.25 \times 10^{-3} \%(\mathrm{w} / \mathrm{v})$ bromphenol blue and 63 $\mathrm{mM}$ Tris- $\mathrm{HCl}, \mathrm{pH} 6.8$. The mixture was heated at $95^{\circ} \mathrm{C}$ for two minutes, and was applied to sodium dodecyl sulfate polyacrylamide gel electrophoresis $(350 \mu \mathrm{g}$ protein per lane). Electrophoresis was done at $40 \mathrm{~mA}$ for 1.5 hr using a $12 \%(\mathrm{w} / \mathrm{v})$ separating gel $(5.5 \mathrm{~cm} \times 7.5 \mathrm{~cm})$ on a Mini-Blot apparatus (Bio-Rad Laboratories, Richmond, CA). The separated proteins on the gel were transferred onto polyvinyl membrane sheet by electrophoresis at $70 \mathrm{~V}$ for one hour at $4^{\circ} \mathrm{C}$ in the transfer buffer containing $20 \%(\mathrm{w} / \mathrm{v})$ methanol and $25 \mathrm{mM}$ Tris-glycine, $\mathrm{pH}$ 8.3. The sheet was incubated in the phosphate buffered saline (PBS, pH 7.2) containing 5\% non-fat milk for $15-18 \mathrm{hr}$ at $4^{\circ} \mathrm{C}$ to block a non-specific antigenantibody reaction. The sheet was incubated with the antiTFA rabbit serum at a dilution of 1:10 in PBS containing $5 \%$ non-fat milk for five hours at $37^{\circ} \mathrm{C}$. After washing three times with PBS for ten minutes, the sheet was then incubated with horseradish peroxidase-conjugated goat anti-rabbit IgG (diluted 1:1000 in PBS with 5\% nonfat milk) for one hour at $37^{\circ} \mathrm{C}$. The sheet was washed twice with PBS containing $0.5 \%$ Tween- 20 and $20 \mathrm{mM}$ Tris- $\mathrm{HCl}, \mathrm{pH} 7.5$, and once with PBS. Finally the sheet was incubated with a fresh peroxidase substrate mixture containing 4-chloro-1-naphthol to stain the reacted proteins.

Patients' sera were diluted to 1:10 in PBS containing $5 \%$ non-fat milk, and immunoblotting was done in the same way, with the exception of horseradish peroxidaseconjugated goat anti-human IgG which was used as a second antibody.

\section{Synthesis of TFA-RSA}

We tried three chemicals to acetylate lysine residues of RSA: $p$-nitrophenyl TFA, ${ }^{16}$ 1-ethyl-3-(3-dimethylaminopropyl) carbodiimide hydrochloride ${ }^{17}$ and TFA anhydride. ${ }^{18}$ Of these, only p-nitrophenyl TFA was able to conjugate TFA to RSA. 
The RSA $50 \mathrm{mg}$ was dissolved in $10 \mathrm{ml}$ of PBS, pH 7.2 , followed by an addition of $p$-nitrophenyl TFA 100 $\mu \mathrm{l}$. The mixture was stirred for two hours at room temperature, then dialyzed three times against two litres of PBS, $\mathrm{pH}$ 7.2. Protein concentration was adjusted to 8 $\mathrm{mg} \cdot \mathrm{ml}^{-1}$ by centrifugation at $3,000 \times \mathrm{g}$ for $30 \mathrm{~min}$ at $4^{\circ} \mathrm{C}$ using Amicon Centriflo 25 (Amicon Co., Bevery, MA).

\section{Confirmation of TFA-RSA synthesis}

\section{ELECTRICAL MOBILITY}

The RSA $100 \mu \mathrm{g}$, TFA-RSA $100 \mu \mathrm{g}$ and normal human serum $100 \mu \mathrm{g}$, respectively, were loaded to the base lines on the cellulose acetate membrane (SEPARAX; Olympus Optical Co. Ltd., Tokyo, Japan) in the barbiturate buffer, pH $8.6(\mu=0.06)$. Electrophoresis was done using AS 600 (Olympus Optical Co. Ltd., Tokyo, Japan) at 0.6 $\mathrm{mA} \cdot \mathrm{cm}^{-1}$ for $30 \mathrm{~min}$ at $4^{\circ} \mathrm{C}$.

\section{PRODUCTION OF RABBIT ANTI-TFA ANTIBODY}

Two rabbits weighing $3 \mathrm{~kg}$ were immunized with TFARSA according to Satoh and colleagues. ${ }^{19}$ They were given $1 \mathrm{mg}$ TFA-RSA in $1 \mathrm{ml}$ of Freund's complete adjuvant in the footpad intramuscularly. After three and four weeks, booster injections were done. Blood samples were taken four to seven weeks after the initial injection. Sera with $0.2 \%$ sodium azide were stored at $4^{\circ} \mathrm{C}$. Another preparation of rabbit antibody against TFA-RSA was a gift from Professor A.J. Gandolfi (The Department of Anesthesiology, University of Arizona, Arizona, USA) who synthesized TFA-RSA by using $S$-ethylthioltrifluoroacetate. This antibody has been shown to recognize rabbit microsomal polypeptides prepared after in in vivo exposure to halothane. ${ }^{20}$

\section{BLOCKING BY TFA-LYSINE}

Immunoblotting in the presence of the rabbit anti-sera against TFA-RSA was done as described above with the exception of adding $50 \mathrm{mM}$ TFA-lysine during incubation.

\section{Results}

The TFA-RSA synthesized with $p$-nitrophenyl TFA moved toward the positive electrode faster than did RSA, indicating that TFA-RSA had a higher negative charge than RSA (Figure 2). Rabbit anti-sera against the newly synthesized TFA-RSA recognized rat liver microsomal polypeptides obtained after in vivo exposure to halothane: $109 \mathrm{kDa}, 92 \mathrm{kDa}, 80 \mathrm{kDa}, 79 \mathrm{kDa}, 76 \mathrm{kDa}, 64 \mathrm{kDa}$ and $59 \mathrm{kDa}$, of which $79 \mathrm{kDa}$ polypeptides were recognized even in the presence of $50 \mathrm{mM}$ TFA-lysine (Figure 3). Rabbit anti-sera against TFA-RSA which were

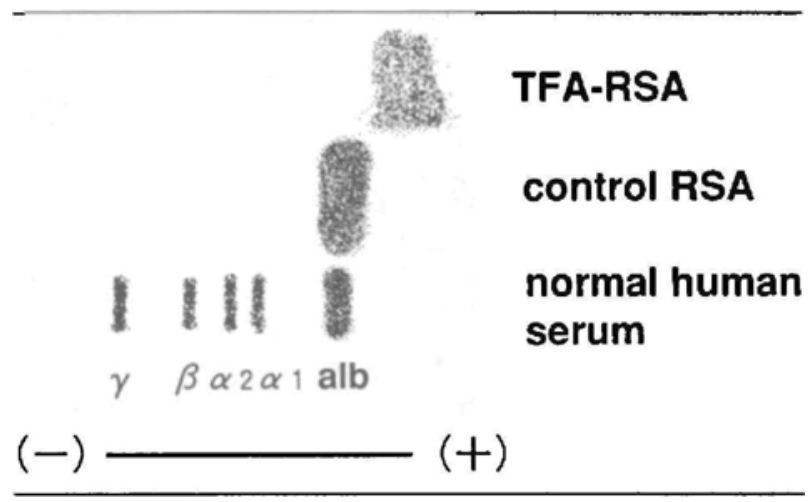

FIGURE 2 Electrical mobility of RSA and the synthesized TFARSA. One hundred micrograms of RSA, TFA-RSA and normal human senum were loaded on the cellulose acetate membrane in the barbiturate buffer, $\mathrm{pH} 8.6(\mu=0.06)$. Electrophoresis was done at 0.6 $\mathrm{mA} \cdot \mathrm{cm}^{-1}$ for $30 \mathrm{~min}$ at $4^{\circ} \mathrm{C}$

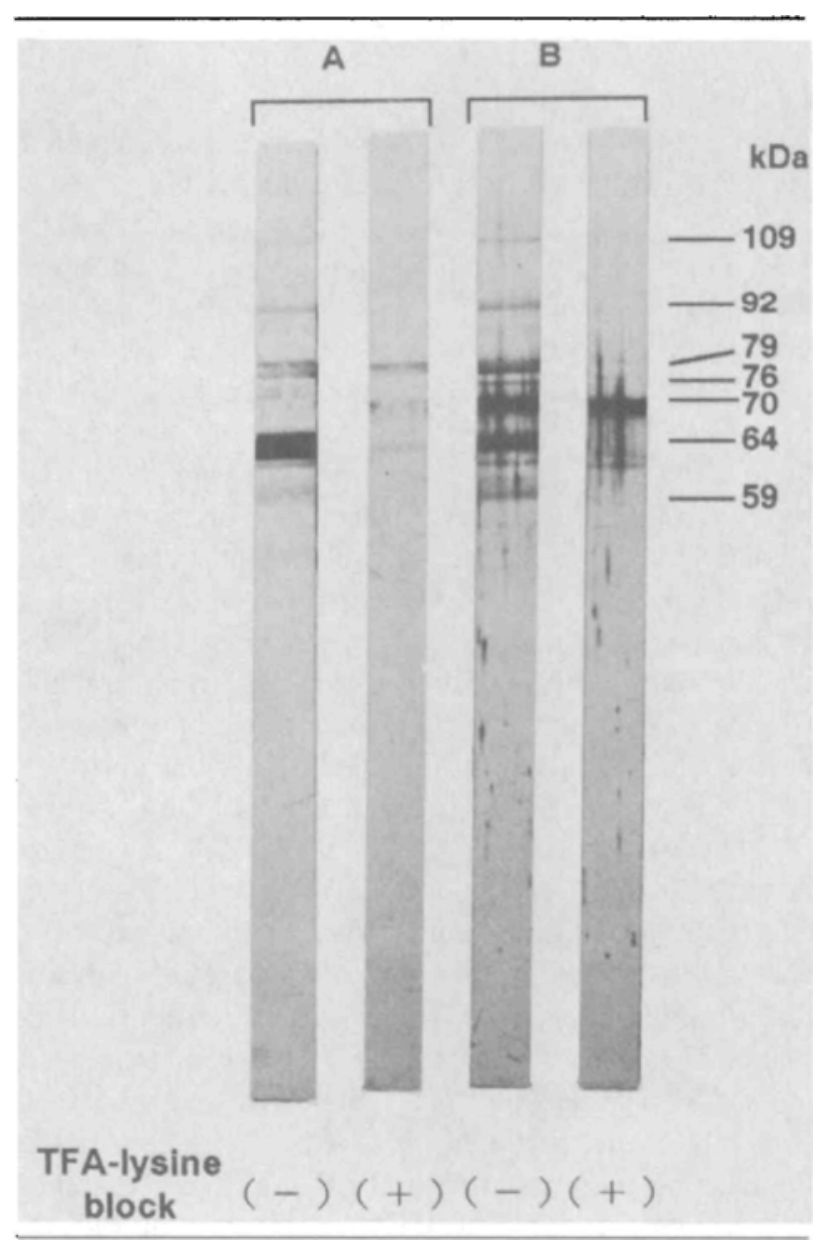

FIGURE 3 Immunoblotting using rabbit anti-sera against TFARSA. Liver microsomal fractions were prepared from rats that had been given ip injection of halothane, $10 \mathrm{mmol} \cdot \mathrm{kg}^{-1}$ in sesame oil, 15 $\mathrm{hr}$ before sacrifice. Antibody overlays were performed with rabbit antisera against TFA-RSA synthesized with $p$-nitrophenyl TFA (A) and $S$ ethylthioltrifluoroacetate (B) at 1:10 dilution in the presence and in the absence of $50 \mathrm{mM}$ TFA-lysine. 
prepared by University of Arizona using $S$-ethylthioltrifluoroacetate recognized $109 \mathrm{kDa}, 92 \mathrm{kDa}, 80 \mathrm{kDa}, 79$ $\mathrm{kDa}, 76 \mathrm{kDa}, 70 \mathrm{kDa}, 64 \mathrm{kDa}, 62 \mathrm{kDa}$ and $59 \mathrm{kDa}$ polypeptides, of which $70 \mathrm{kDa}$ and $62 \mathrm{kDa}$ polypeptides were recognized even in the presence of $50 \mathrm{mM}$ TFAlysine. This confirms that our anti-sera against TFA-RSA have specific antibodies against TFA-conjugated polypeptides.

Immunoblotting revealed that 84 of 86 serum samples from patients receiving halothane anaesthesia recognized no rat liver microsomal polypeptides obtained after an in vivo exposure to halothane (not shown). One serum recognized $84 \mathrm{kDa}$, and another $71 \mathrm{kDa}$ polypeptide, but these reactions were not blocked in the presence of $50 \mathrm{mM}$ TFA-lysine. Furthermore, these two sera recognized the corresponding polypeptides obtained without exposure to halothane, indicating that neither of these two sera had anti-TFA antibodies.

\section{Discussion}

Rabbit anti-sera against TFA-RSA have been reported to recognize the rat microsomal distorted polypeptides in almost the same way as do sera from patients with $\mathrm{HH}$, implying ease in establishing an assay for the detection of patients sensitized to halothane if a TFAconjugated protein can be synthesized. Although the $S$ ethylthioltrifluoroacetate used to synthesize TFA-RSA by Satoh et al. ${ }^{19}$ is not presently commercially available, there remain several methods for modifying the lysine residues of RSA. We have succeeded in synthesizing TFA-RSA using $p$-nitrophenyl TFA. If the carboxyl residue of TFA binds to the amino residues of RSA, the modified RSA should bear a higher negative charge than the untreated RSA, which has been shown electrophoretically in this experiment. Furthermore, rabbit anti-sera against our TFA-RSA have been shown to recognize the same polypeptides: $109 \mathrm{kDa}, 92 \mathrm{kDa}, 80 \mathrm{kDa}, 76 \mathrm{kDa}$, $64 \mathrm{kDa}$ and $59 \mathrm{kDa}$ as the anti-TFA-RSA anti-serum prepared by the Arizona group. We have also observed that our anti-sera are unable to recognize these polypeptides in the presence of TFA-lysine. These results indicate that our anti-sera against TFA-RSA contain specific antibodies against TFA-conjugated polypeptides. Our method of synthesizing TFA-RSA is more convenient than any of the methods previously reported, because the reaction succeeds at neutral $\mathrm{pH}$. Our method seems to give further insight into $\mathrm{HH}$; e.g., establishing ELISA for detection of anti-TFA antibody and for differential diagnosis of $\mathrm{HH}$.

We observed that 86 sera of patients anaesthetized with halothane not followed by $\mathrm{HH}$ have no antibodies against rat liver microsomal polypeptides obtained after an in vivo exposure to halothane, which have previously been reported to be recognized by sera of patients with $\mathrm{HH}$. Our findings support the hypothesis that the appearance of circulating antibodies against microsomal distorted proteins are specific to patients with $\mathrm{HH}$ and not seen in the sera of patients without HH. Furthermore, we have shown here that the halothane-induced mild increase in ALT activity is not associated with the appearance of circulating antibodies, which supports a pathophysiological difference between $\mathrm{HH}$ and halothane-induced mild hepatic damage. Recently, Gut et al. found that the cross-reactive polypeptides of $52 \mathrm{kDa}$ and $64 \mathrm{kDa}$, which were recognized by the anti-TFA antibodies, are also detected in liver biopsy specimens of patients who had never received halothane anaesthesia. ${ }^{21}$ They speculated that patients who escape $\mathrm{HH}$ have been exposed to TFA before the completion of T-cell training, and that only rare patients, those not exposed to TFA during the embryonic and infantile periods, might possibly develop $\mathrm{HH}$ after halothane anaesthesia.

Kenna et al. reported that the anti-TFA sera recognize rat liver microsomal polypeptides either partially, maximally or almost not at all if the liver is obtained $3 \mathrm{hr}$, $18 \mathrm{hr}$ or seven days respectively after the administration of halothane. ${ }^{22}$ This observation indicates that the amount of the TFA-conjugates is reduced within a few days, and that the antigen stimulation by TFA-conjugate continues only for a short duration. In the case of viral hepatitis, its severity and prognosis have been suggested to depend on the balance between the number of virusinfected liver cells and the functional reserve of cytotoxic T-cells. ${ }^{23}$ Therefore, it might be speculated that $\mathrm{HH}$ does not pass into the chronic state. On the other hand, the correlation between the amount of antigen and the severity of $\mathrm{HH}$ has not been resolved. Although the rate of biotransformation of enflurane and isoflurane has been reported to be one or two magnitudes respectively lower than that of halothane, enflurane and isoflurane also produce reactive intermediates which would form acetylated hepatic protein adducts. The final metabolite of isoflurane is identified as TFA. Whether the number of hepatocytes containing TFA-adducts after isoflurane anaesthesia is less than after halothane anaesthesia needs to be resolved.

The possibility exists that the specific antibodies had not yet been produced or had already disappeared from the patients' sera we examined. In general, antibody appears in serum one to two weeks after immunization, and disappears within about three months without a booster. Of our 86 sera, 63 had been taken from two to 12 weeks after halothane anaesthesia. Hubbard et al. reported that anti-TFA antibodies appeared four days after the administration of halothane in one patients with $\mathrm{HH}$, and remained elevated for three months following 
halothane anaesthesia in another. ${ }^{12}$ We have failed to detect any antibodies in the serum from a patient who had developed $\mathrm{HH}$ ten years ago and survived by repetitive plasmapheresis (not shown).

In summary, a new method of synthesizing TFA-RSA using $p$-nitrophenyl TFA was performed successfully. No circulating antibodies were detected by immunoblotting in 86 patients who had received halothane anaesthesia and developed no or mild liver damage, none of whom developed $\mathrm{HH}$. Because new inhaled anaesthetic drugs are also metabolized in the liver and thus have the possibility of producing reactive haptens, the mechanism of halothane hepatitis should be further elucidated. Clarification of the pathogenesis of mild liver damage after exposure to inhalation anaesthetics is also important.

\section{Acknowledgements}

This work was supported by a Grant-in-Aid for Scientific Research from the Ministry of Education, Science and Culture of Japan. We wish to thank Tadashi Ueda D.PHARM.SCI. (Faculty of Pharmaceutical Sciences, Kyushu University) for his advice about the synthesis of TFARSA and Prof. A.J. Gandolfi (Department of Anesthesiology, University of Arizona, Arizona, USA) for his kind provision of his rabbit anti-sera.

\section{References}

1 Ray $D C$, Drummond GB. Halothane hepatitis. $\mathrm{Br} \mathrm{J}$ Anaesth 1991; 67: 84-99.

2 Sakaguchi $Y$, Inaba S, Umeki Y, et al. Retrospective study of post-anesthetic mild liver disorder associated with inhalation anesthetics, halothane and enflurane. Masui 1992; 6: 183-91.

3 Takahashi S, Shigematsu A, Furukawa T. Interaction of volatile anesthetics with rat hepatic microsomal cytochrome P-450. Anesthesiology 1974; 41: 375-9.

4 Stock JGL, Strunin L. Unexplained hepatitis following halothane. Anesthesiology 1985; 63: 424-39.

5 Hubbard $A K$, Gandolfi AJ, Brown BR. Immunological basis of anesthetic-induced hepatotoxicity (Editorial). Anesthesiology 1988; 69: 814-7.

6 Neuberger J, Kenna JG. Halothane hepatitis: a model of immune mediated drug hepatotoxicity (Editorial). Clin Sci 1987; 72: 263-70.

7 Elliott RH, Strunin L. Hepatotoxicity of volatile anaesthetics. Br J Anaesth 1993; 70: 339-48.

8 Karashima D, Takahashi S, Shigematsu A, Furukawa $T$. The gas chromatographic mass spectrometric determination of trifluoroacetic acid in biological fluid. Application to halothane metabolism. Biomedical Mass Spectrometry 1976; 3: 41-4.

9 Karashima D, Hirokata Y, Shigematsu A, Furukawa $T$. The in vitro metabolism of halothane (2-bromo-2-chloro- 1,1,1-trifluoroethane) by hepatic microsomal cytochrome P-450. J Pharmacol Exp Ther 1977; 203: 409-16.

10 Kenna JG, Satoh H, Christ DD, Pohl LR. Metabolic basis for a drug hypersensitivity: antibodies in sera from patients with halothane hepatitis recognize liver neoantigens that contain the trifluoroacetyl group derived from halothane. J Pharmacol Exp Ther 1988; 245: 1103-9.

11 Martin JL, Kenna JG, Pohl LR. Antibody assays for the detection of patients sensitized to halothane. Anesth Analg 1990; 70: 154-9.

12 Hubbard AK, Roth TP, Gandolfi AJ, Brown BR Jr, Webster NR, Nunn JF. Halothane hepatitis patients generate an antibody response toward a covalently bound metabolite of halothane. Anesthesiology 1988; 68: 791-6.

13 Bird GLA, Williams $R$. Detection of antibodies to a halothane metabolite hapten in sera from patients with halothane-associated hepatitis. J Hepatol 1989; 9: 366-73.

14 Subcommittee on the National Halothane Study of the Committee on Anesthesia National Academy of Science National Research Council. Summary of the National Halothane Study. JAMA 1966; 197: 775-88.

15 Sakai H, Hino Y, Minakami S. Three immunoidentical cytochrome $\mathbf{P}-450$ from liver microsomes of phenobarbitaltreated rats. Biochem J 1983; 215: 83-9.

16 Adriaensens P, Box ME, Martens HJ, Onkelinx E, Put J, Gelan $J$. Investigation of protein structure by means of 19F-NMR: a study of hen egg-white lysozyme. Eur J Biochem 1988; 177: 383-94.

17 Oliver GC, Parker BM, Brisfield DL, Parker CW. The measurement of digotoxin in human serum by radioimmunoassay. J Clin.Invest 1968; 47: 1035-42.

18 Montelaro $R C$, Rueckert $R R$. Radiolabeling of proteins and viruses in vitro by acetylation with radioactive acetic anhydride. J Biol Chem 1975; 250: 1413-21.

19 Satoh H, Fukuda Y, Anderson DK, Ferrans VJ, Gillette $J R$, Pohl $L R$. Immunological studies on the mechanism of halothane-induced hepatotoxicity: immunohistochemical evidence of trifluoroacetylated hepatocytes. J Pharmacol Exp Ther 1985; 233: 857-62.

20 Roth TP, Hubbard AK, Gandolfi AJ, Brown BR. Chronology of halothane-induced antigen expression in halothaneexposed rabbits. Clin Exp Immunol 1988; 72: 330-6.

21 Gut J, Christen U, Huwyler J, Bürgin M, Kenna JG. Molecular mimicry of trifluoroacetylated human liver protein adducts by constitutive proteins and immunochemical evidence for its impairment in halothane hepatitis. Eur $\mathbf{J}$ Biochem 1992; 210: 569-76.

22 Kenna JG, Martin $J L$, Satoh $H$, Pohl LR. Factors affecting the expression of trifluoroacetylated liver microsomal protein neoantigens in rats treated with halothane. Drug Metab Dispos 1990; 18: 788-93.

23 Almeida $J D$, Waterson $A P$. Immune complexes in hepatitis. Lancet $1969 ; 2$ : 983-6. 